\title{
NUTRITION AND WHOLE-BODY PROTEIN TURNOVER IN THE CHICKEN IN RELATION TO MAMMALIAN SPECIES
}

\author{
TATSUO MURAMATSU
}

Laboratory of Animal Nutrition, School of Agriculture, Nagoya University, Chikusa-ku, Nagoya 464-01, Japan

CONTENTS

INTRODUCTION . . . . . . . . . . . . . . . . 211

CHRONIC EFFECTS . . . . . . . . . . . . . . . . . . . 213

PROTEIN SYNTHESIS AND REQUIREMENTS FOR PROTEIN AND/OR ENERGY 213

AMINO ACID DEFICIENCY . . . . . . . . . . . . . . . . . . . 218

AMINO ACID ADDITION TO A PROTEIN-FREE DIET . . . . . . 219

ACUTE EFFECTS . . . . . . . . . . . . . . . . . . . . . 220

FASTING AND REFEEDING A DIET OR SPECIFIC NUTRIENTS . . . . . 220

PROTEIN DEPLETION AND REPLETION . . . . . . . . . . . . . 222

OUTLOOK AND CONCLUSIONS . . . . . . . . . . . . . . . . . . . $\quad . \quad 224$

REFERENCES . . . . . . . . . . . . . . . . . 225

\section{INTRODUCTION}

Since the first indication by Schoenheimer (1942) of the dynamic state of body protein, it is well established that intracellular proteins are subject to substantial synthesis and degradation processes. As a result, accretion of protein in the whole body of animals is the reflection of small differences between synthesis and degradation rates. Because protein accretion, hence overall growth at early stages or egg, wool and milk production at maturity, is one of the major concerns in livestock husbandry as well as for human nutrition, there has been increasing interest in the regulation of these processes in recent years.

Investigation into the influence of nutrients on protein synthesis and degradation rates, expressed as either fractional rates $(\% / \mathrm{d})$ or absolute rates $(\mathrm{g} / \mathrm{d}$ or $\mathrm{g} / \mathrm{kg}$ bodyweight ${ }^{0.75}$ per $d$ ) in the present review, in the whole body of animals has been greatly facilitated by the establishment of techniques for measuring synthesis rates in vivo such as continuous infusion (Waterlow et al. 1978) and large dose injection (McNurlan et al. 1979; Garlick et al. 1980 b). Currently, estimates of protein degradation still depend mostly on indirect values deduced by subtracting growth rates from synthesis rates of body protein, due primarily to lack of adequate methods. Thus, any speculations relating to protein degradation in the present review are derived from such indirect measurements. Details of problems associated with the measurement of protein synthesis and degradation rates are reviewed elsewhere (Waterlow et al. 1978; Zak et al. 1979).

In the present review, the term 'protein turnover' is frequently used. However, its meaning is not always clear to everyone and, as Schimke (1970) pointed out, there has been confusion in the use of the term. In the following discussion, the term 'protein turnover' 
Table 1. Comparison of the rate of whole-body protein synthesis in adult mammalian and avian species

\begin{tabular}{|c|c|c|c|}
\hline Species & Body-wt (kg) & $\begin{array}{l}\text { Whole-body protein synthesis } \\
\left(\mathrm{g} / \mathrm{kg} \text { body-w } \mathrm{w} t^{075} \text { per } \mathrm{d}\right)\end{array}$ & Reference \\
\hline \multicolumn{4}{|l|}{ Mammals } \\
\hline Mouse & 0.03 & 18.6 & Muramatsu et al. (1985a) \\
\hline Rat & 0.51 & 17.4 & Waterlow et al. (1978) \\
\hline \multirow{2}{*}{ Rabbit } & 3.6 & $15 \cdot 0$ & Reeds \& Lobley (1980) \\
\hline & 3.6 & $19 \cdot 0$ & Waterlow et al. (1978) \\
\hline \multirow{2}{*}{ Goat } & 38 & 16.4 & Muramatsu et al. $(1988 a)$ \\
\hline & $30-40$ & $12 \cdot 0-26 \cdot 2$ & Muramatsu et al. (1989) \\
\hline \multirow{2}{*}{ Sheep } & 40 & 15.9 & Waterlow et al. (1978) \\
\hline & 63 & $15 \cdot 7$ & Reeds \& Lobley (1980) \\
\hline \multirow{2}{*}{ Man } & 62 & $12 \cdot 5$ & Reeds \& Lobley (1980) \\
\hline & 77 & 16.7 & Waterlow et al. (1978) \\
\hline \multirow{2}{*}{ Cattle } & 500 & $16 \cdot 1$ & Reeds \& Lobley $(1980)$ \\
\hline & 628 & $16 \cdot 1$ & Lobley et al. (1980) \\
\hline \multicolumn{4}{|r|}{ - } \\
\hline \multirow[t]{3}{*}{ Chicken } & 1.38 & $29 \cdot 2$ & Muramatsu et al. (1987b) \\
\hline & 1.55 & $31 \cdot 2$ & Muramatsu et al. (1987c) \\
\hline & 1.55 & $30 \cdot 3$ & Hiramoto et al. (1989) \\
\hline
\end{tabular}

does not refer exclusively to the degradation process, as used by some authors, but generally to both synthesis and degradation processes, which are independently, though harmoniously, controlled in response to shifts of nutritional and physiological conditions. Only in a steady state, which is a special and limited instance of the more general condition, are the rates of the two processes the same.

The aim of the present paper is to investigate whether birds and mammals share the same underlying regulatory mechanisms in response to alterations in nutritional status. For this purpose, comparisons of avian species (i.e. chickens) with mammalian species are made in the area of whole-body turnover in relation to nutrient intake. In the well-fed state, when expressed as $\mathrm{g} / \mathrm{kg}$ body-weight ${ }^{0.75}$ per $\mathrm{d}$, the rates of whole-body protein synthesis are considerably higher in avian compared with mammalian species (Table 1), and probably so are the protein degradation rates. One of the reasons for this high rate of protein synthesis in chickens could be attributable to high body temperature, $41.7^{\circ}$ compared with $37.0^{\circ}$ for rats and humans, a difference that might account for about a $40 \%$ increase in protein synthesis (Laurent et al. 1978). Alternatively, some of the differences may also be ascribable to the different methods employed. Therefore, no direct comparison is made merely by comparing the absolute turnover rate between species but by looking at the responsiveness to changes in nutrient intake.

For the sake of convenience, separate considerations will be made of chronic effects such as results from the same dietary regimen for several days, and the acute, transient impact of dietary nutrient intake observed from day to day or within a single day. These time scales were chosen by assuming that a new steady state of whole-body protein turnover rates would be obtained within a few days of a change in diet. This was based on the fact that in chickens basal metabolism is attained after only $24 \mathrm{~h}$ of fasting in young chicks and a few days at most are necessary in adult fowls (Freeman, 1971), and that there appears to be a close relationship between whole-body protein turnover rates and energy metabolism (Waterlow et al. 1978; Webster, 1981, 1983; Muramatsu \& Okumura, 1985).

Whether an experimental period is long enough to be classified as a chronic effect would 
depend, in the first place, on species, age and body size of the animals to be examined. In humans, for example, a 3-week trial may not be long enough to establish reasonably constant rates of protein turnover in the whole body by changing dietary amino acid levels, as discussed by Young et al. (1987). On the other hand, a 1-week experiment may be quite long enough for attaining relatively constant rates of protein turnover in laying hens (Muramatsu et al. $1987 \mathrm{~b}, \mathrm{c}$ ). In addition, the habits of food consumption vary from one species to another. In chickens, especially when they are young, the food is consumed throughout the day, whereas in humans nutrients are normally consumed as discrete meals. It follows, therefore, that for chickens on the one hand, a pseudo-steady state of wholebody protein turnover is attained as a consequence of an almost continual supply of nutrients. For humans, on the other hand, it is attained after repeated cycles of postabsorptive and feeding states. Thus, it should be born in mind that the definition of chronic or acute in the present review is provisional.

\section{CHRONIC EFFECTS}

\section{PROTEIN SYNTHESIS AND REQUIREMENTS FOR PROTEIN AND/OR ENERGY}

This section is devoted to elucidating the effects on whole-body protein synthesis of varying dietary protein or energy intakes, with particular emphasis on the requirements for these components.

As far as growing animals are concerned, whether avian or mammalian species, it would be fair to state that the requirement for protein is generally recognized as the level at which maximal growth and protein deposition are obtained. In this regard, the results in chickens imply that growth and whole-body protein kinetic measurements are closely related. Protein synthesis in the whole body of this species increased with increasing dietary protein intake up to an adequate level, and at above the optimum level no further increases were observed (Muramatsu et al. 1987d). Muramatsu et al. (1988b) examined in more detail the relationships between dietary protein-intake and growth, protein retention or whole-body synthesis in young chicks. The results are shown in Fig. 1, where the responses to altered protein intakes are expressed as a non-linear mathematical equation described by Mercer (1982). As shown clearly, the responses of each of these variables exhibited similar sigmoidal curves, the $90 \%$ asymptotic maximum values of which were obtained at $2 \cdot 7,3.0$ and $2.9 \mathrm{~g}$ protein intake/ $\mathrm{d}$ for body-weight gain, protein retention, and whole-body protein synthesis respectively. These values all confirm the recommended requirement of daily protein intake for optimal growth of $3.0 \mathrm{~g}$, for birds of a similar body-weight (Scott et al. 1982).

In mammalian species, a comparable result has been reported. In rats protein synthesis in the whole body was increased with diets containing up to $200 \mathrm{~g}$ protein $/ \mathrm{kg}$, above which no further increase was observed and the synthesis rate remained constant (Laurent $e t$ al. 1984). Although no detailed quantitative estimation was made, yet the dietary level giving maximal protein synthesis would be in line with the dietary protein level of $150-200 \mathrm{~g} / \mathrm{kg}$, as recommended by National Research Council (1978).

In an essentially similar way to dietary protein intake, metabolizable energy (ME) intake may affect whole-body protein synthesis. Kita et al. $(1989 b)$ found in young chicks given a constant protein intake that when $\mathrm{ME}$ intake was deficient, protein synthesis rates decreased almost proportionally, whereas when $M E$ intake was more than adequate, they remained constant. Fig. 2 shows the relationships between $M E$ intake and body-weight gain, protein retained or whole-body protein synthesis with predicted curves from the non- 


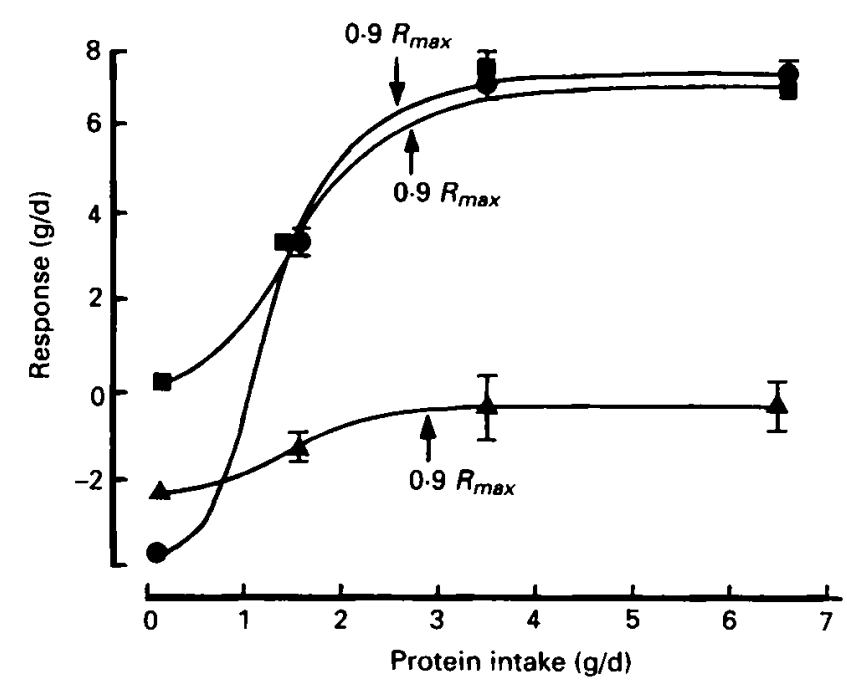

Fig. 1. Response curves in young in chicks of body-weight gain (O), protein retention ( $\mathbf{\Delta}$ ) and wholebody protein synthesis $(\boldsymbol{a}) v$. protein intake obtained by a four-parameter mathematical model (Mercer, 1982):

$$
R=\left(b\left(K_{0 \cdot 5}\right)^{n}+R_{\text {max }}(P)^{n}\right) /\left(\left(K_{0 \cdot 5}\right)^{n}+(P)^{n}\right) .
$$

where $R, P I, R_{m a x}, n$ and $K_{0 \cdot 5}$ are response $(\mathrm{g} / \mathrm{d})$, protein intake $(\mathrm{g} / \mathrm{d})$, asymptotic maximum response, apparent kinetic order, and the intake for $0.5\left(R_{\max }+b\right)$ respectively; $b$ is the intercept on the response axis. Each response was well described by the regression equation with high $R^{2}, 0.98,0.98$ and 0.87 for body-weight gain, protein retention and whole-body protein synthesis respectively. Points are means with their standard errors represented by vertical bars. (Taken from Muramatsu $e t a l .1988 b$ ).

linear regression equations described by Mercer (1982). The $90 \%$ asymptotic maximum values for each variable were obtained at 155,134 and $146 \mathrm{~kJ} / \mathrm{d}$ for body-weight gain, protein retained and whole-body protein synthesis respectively, indicating that the value for whole-body protein synthesis fell between the other two variables that have usually been used as criteria of dietary energy requirements for growing birds. It should also be noted that the energy intake obtained at $90 \%$ asymptotic maximum values was close to, though slightly lower than, the recommended requirement of $156 \mathrm{~kJ} / \mathrm{d}$ (National Research Council, 1984) and $163 \mathrm{~kJ} / \mathrm{d}$ (Scott et al. 1982) for chickens of similar age and weight.

These findings from chickens are not definitive, but they suggest that there might be a close link between dietary energy requirement and whole-body protein synthesis, at least in this avian species. As for mammalian species, it has yet to be established whether a similar relationship exists, since no study has examined the effect of changes in ME intake with adequate supply of protein in sufficient detail to allow a quantitative analysis of wholebody protein synthesis and dietary energy requirement. The only studies which have been reported tend to involve a single level of dietary restriction (e.g. in obese human subjects, Garlick et al. 1980 a). It is not known how far birds differ from mammals in response to ME intake per se.

As can be seen in the foregoing sections, altered protein and ME intakes brought about analogous responses of whole-body protein synthesis in the chicken. The question then arises whether these responses are caused through the same mechanism. Reeds \& Fuller (1983) suggested from their findings in pigs (Reeds et al. 1981) that the effects of dietary protein and energy on protein metabolism are additive. This will suggest that they are probably brought about by different mechanisms linked to whole-body protein turnover. 


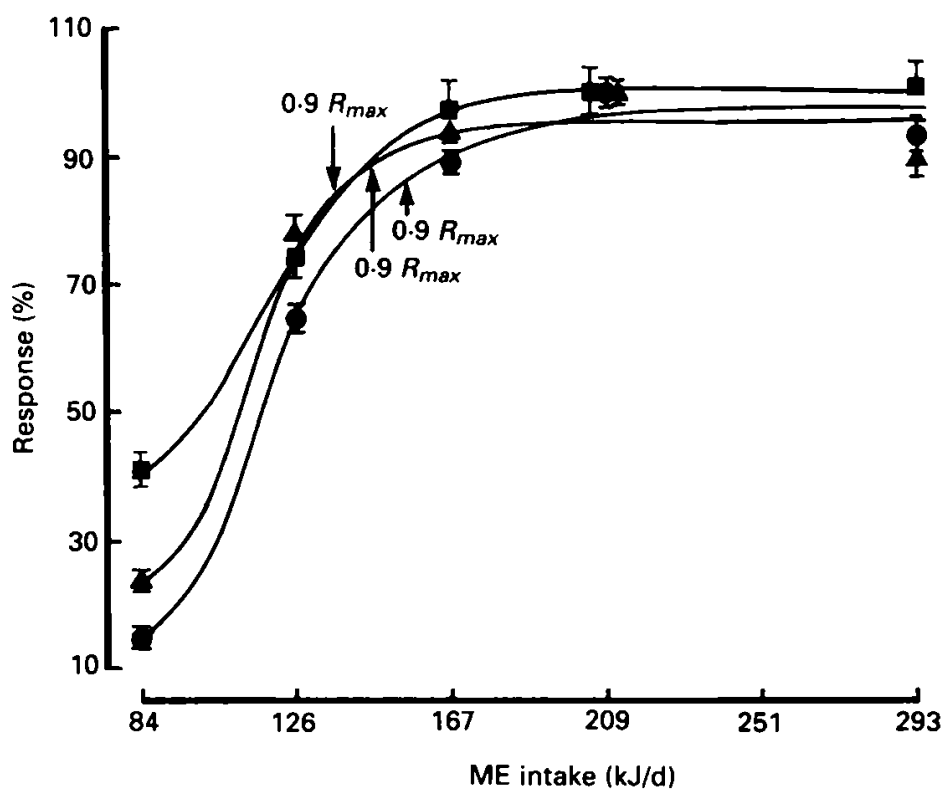

Fig. 2. Response curves in young chicks of body-weight gain ( $\boldsymbol{O})$, protein retention $(\mathbf{\Delta})$ and whole-body protein synthesis $(\square) v$. dietary metabolizable energy (ME) intake obtained by a four-parameter mathematical model (Mercer, 1982):

$$
R=\left(b\left(K_{0.5}\right)^{n}+R_{m a x}(P)^{n}\right) /:\left(K_{0 \cdot 5}\right)^{n}+\left(P I^{n}\right),
$$

where $R, P I, R_{m a x}, n$ and $K_{0.5}$ are response $(\mathrm{g} / \mathrm{d})$, protein intake $(\mathrm{g} / \mathrm{d})$, asymptotic maximum response, apparent kinetic order, and the intake for $0.5\left(R_{\max }+b\right)$ respectively; $b$ is the intercept on the response axis. Points are means with their standard errors represented by vertical bars.

In attempting to provide evidence in chickens, a detailed factorial experiment was conducted to clarify the effects on whole-body protein synthesis of protein and ME intakes, both at deficient, adequate and excess levels (K. Kita, T. Muramatsu \& J. Okumura, unpublished results). The values are presented as a three-dimensional response surface to illustrate the complicated response in a visual and comprehensible form (Fig. 3).

Some conclusions can be drawn from the response shown in Fig. 3. First, whole-body protein synthesis may be substantially influenced by the levels of both protein and $\mathrm{ME}$ intakes. The effect of increasing ME intake was smaller at deficient protein intake than at adequate or excess protein intake. Similarly, the effect of increasing protein intake was more obvious at adequate or excess ME intake than at deficient ME intake. Therefore, because of these separate influences of protein and $\mathrm{ME}$ intakes it is of primary importance to clarify at which level the starting point is set, and to describe the magnitude of the change in order to examine the response to alterations in these dietary components. Second, in the deficient region for both protein and energy, the effect on whole-body synthesis of increasing intake by $1 \mathrm{~kJ}$ protein appeared to be larger than that of increasing intake by $1 \mathrm{~kJ}$ total ME. When the scales for protein and total ME intakes in Fig. 3 are adjusted to be the same, the slope is clearly much steeper towards changes in protein intake. Third, the calculated maximum rates of whole-body protein synthesis were obtained at 154 and $155 \%$ of the requirement levels of dietary protein and $\mathrm{ME}$ intakes respectively according to the values recommended by Scott et al. (1982). At the recommended requirement levels ( $52 \mathrm{~kJ}$, i.e. $3 \mathrm{~g} / \mathrm{d}$ for protein and $167 \mathrm{~kJ} / \mathrm{d}$ for $\mathrm{ME}$ ), however, the value for whole-body protein 


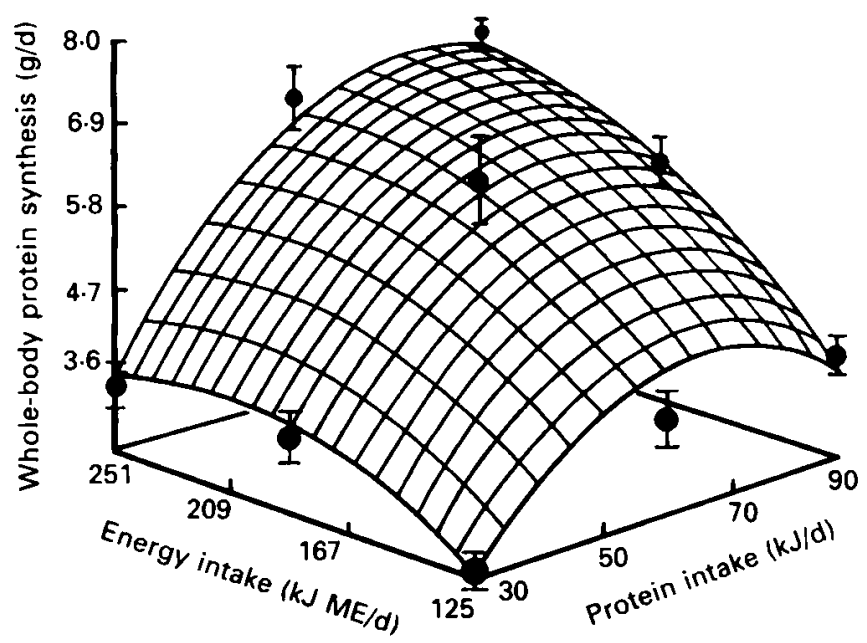

Fig. 3. Response surface of whole-body protein synthesis in chicks fed at varying dietary protein and total energy intakes. Values are means with their standard errors represented by vertical bars. ME, metabolizable energy. (Taken from K. Kita, T. Muramatsu \& J. Okumura, unpublished results).

synthesis had already reached $87 \%$ of the maximum. The fact that essentially similar responses of body-weight gain and protein retained were found in the same experiment suggests again the possible usefulness of whole-body protein synthesis as an index of dietary protein and ME requirements in growing chickens.

The conclusion emerging from the previously mentioned experiment on chickens might not be directly applicable to other animal species. In these species existing evidence is more conflicting and complex so that it is more difficult to draw firm conclusions. For example, little effect of energy intake on whole-body protein kinetics has been reported in humans (Garlick et al. 1980a; Winterer et al. 1980), whereas Hoffer et al. (1984) found a reduction in whole-body protein synthesis of obese human subjects when energy intake was severely restricted.

To illustrate the relationship between whole-body protein synthesis and protein or ME intake more clearly, in the search for a complete picture of controls of whole-body protein synthesis by these dietary components, various literature sources covering several species were examined, and the relationship between whole-body protein synthesis, protein intake and ME intake was analysed with respect to their requirements. Fig. 4 shows the levels of dietary protein and ME intakes at which whole-body protein synthesis was measured in twenty-two studies available in the literature. The scatter or the measurement points in Fig. 4 suggests that speculation on response trends should only be made by pooling the results from a whole class. No single class consisting of several studies could cover the requirement region over a sufficiently wide range except for chickens.

Multiple regression of protein synthesis $v$. intakes of dietary protein and ME was calculated and only the terms significant at $P<0.05$ were included in the corresponding models. The resultant regression equations for chickens, human subjects, non-human mammalian species including rats, pigs and cattle, and pooled classes were as follows:

(1) chickens

$$
\begin{aligned}
P S= & 14.05+0.2025 P I-0.000637 P I^{2}, \\
& \left(R^{2} 0.58, P<0.001, \text { d.f. } 41\right),
\end{aligned}
$$



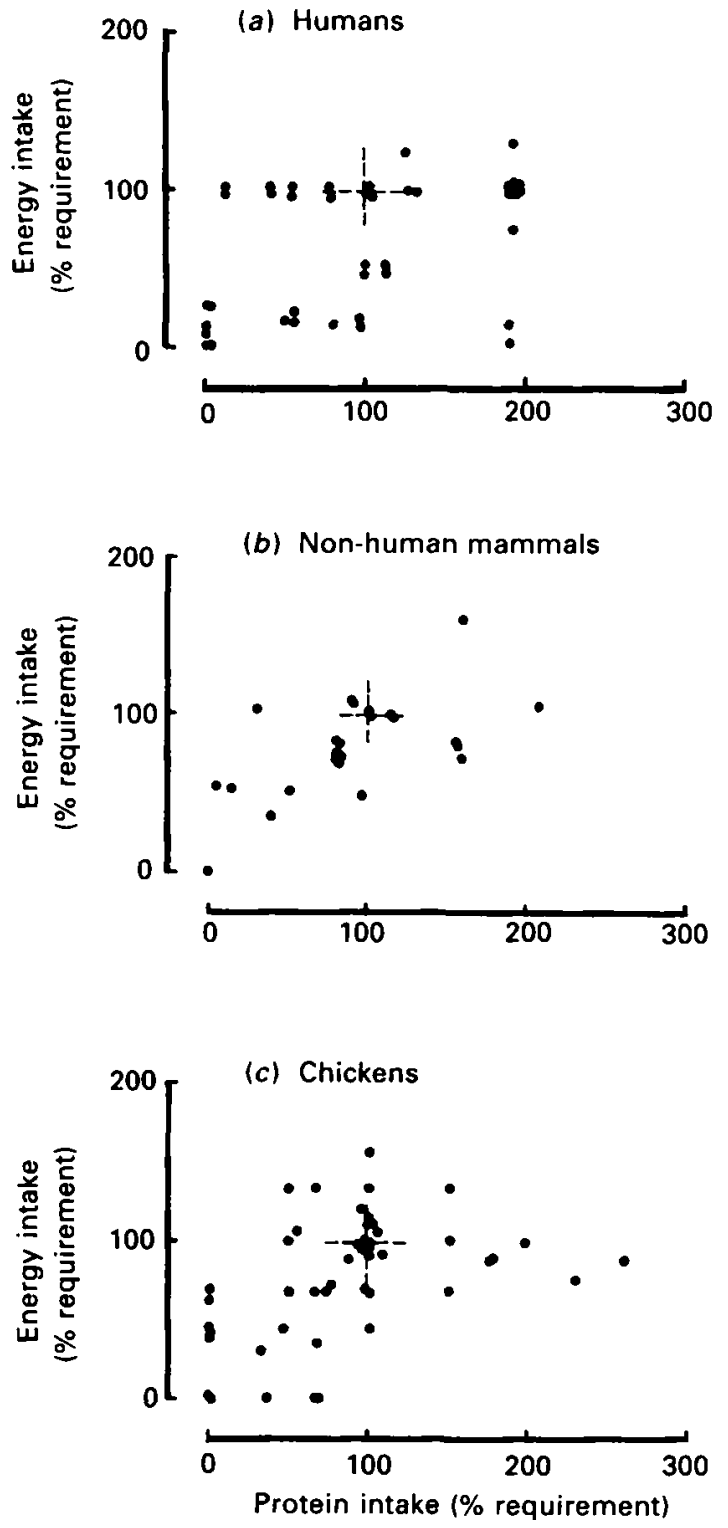

Fig. 4. Distribution of measurement points of dietary protein and energy intakes at which whole-body protein synthesis was determined in the literature. The values were taken from twenty-two studies, covering human subjects, non-human mammalian species and chickens, and were expressed with respect to percentage of requirements for both protein and energy intakes. The sources were: Conway et al. (1980), Garlick et al. (1980 a), Gersovitz et al. (1980), Reeds et al. (1980), Winterer et al. (1980), Motil et al. (1981 $a, b)$, Reeds et al. (1981), Adibi et al. (1982), Hoffer et al. (1984), Laurent et al. (1984), Muramatsu et al. (1986), Yang et al. (1986), Fuller et al. (1987), Lobley et al. (1987), Muramatsu et al. ( $1987 a, b c, d)$, Kita et al. (1989a,b), and K. Kita, T. Muramatsu \& J. Okumura (unpublished results). Where necessary, conversion of amino acid flux to protein flux was done according to the amino acid content in the whole body (Smith, 1980). 
(2) human subjects

$$
\begin{gathered}
P S=6.50+0.0194 P I-0.000063 P I^{2}+0.2665 M E I, \\
\left(R^{2} 0.333, P<0.001,\right. \text { d.f. 33), }
\end{gathered}
$$

(3) non-human mammalian species (rats, pigs and cattle)

$$
\begin{gathered}
P S=8.99+0.2025 P I-0.000637 P I^{2}, \\
\left(R^{2} 0.421, P<0.001, \text { d.f. } 19\right),
\end{gathered}
$$

(4) pooled (1, 2 and 3 included).

$$
\begin{gathered}
P S=10.98+0.0612 P I-0.000214 P I^{2}+0.07481 M E I, \\
\left(R^{2} 0.178, P<0.001, \text { d.f. } 99\right),
\end{gathered}
$$

where $P S, P I$ and $M E I$ are whole-body protein synthesis $\left(\mathrm{g} / \mathrm{kg}\right.$ body-weight $\left.{ }^{0.75} / \mathrm{d}\right)$, dietary protein intake (\% requirement) and dietary $\mathrm{ME}$ intake (\% requirement).

A quadratic response of whole-body protein synthesis to dietary protein intake indicates that there is an optimal protein intake to give maximum values ranging from 130 to $159 \%$ of the dietary protein requirements for individual classes. However, the response has already reached $93-98 \%$ of the corresponding maximum values at the recommended requirement level of dietary protein intake. In contrast, the effect of $\mathrm{ME}$ intake in individual classes is not significant, except for humans. These results, indicating that the effect of $\mathrm{ME}$ in birds and non-human mammals failed to reach statistical significance, were unexpected. Inter-experimental variations may have offset the ME effect. In addition, the results for chickens and non-human mammalian species were obtained primarily from experiments where animals were growing, whilst those for humans were derived mostly from experiments at adulthood. The difference in age might be partly responsible for the differences in responses.

In the pooled classes, there are quadratic and linear effects of protein intake and $\mathrm{ME}$ intake respectively, with relatively poor fit $\left(R^{2} 0 \cdot 178\right)$ which is ascribed primarily to interclass variations. Because of this large variation, a careful interpretation should be given to the regression equation for the pooled classes. Even the definition of 'requirements' would be different between human subjects and growing animals. So-called 'allowance' frequently used in human studies, which is considered here in the present review as 'requirement', includes a safety margin, say $30 \%$, on top of the minimal needs of dietary protein intake. By contrast 'requirements' in studies with farm livestock and laboratory animals may correspond to the minimal value that would produce maximal growth and protein retention. Thus, the regression equations are considered approximate and provisional. Nevertheless, it does appear that whole-body protein synthesis in avian and non-human mammalian species responds in a similar way to these two major dietary components. The fact that there appear to be no considerable deviations of the results in chickens from those in non-human mammalian species suggests that the regulatory mechanisms of whole-body protein synthesis in response to dietary changes in protein and/or ME are the same in avian and non-human mammalian species, although there is no a priori reason why this should be so. The way in which protein synthesis in various animal species is related to the requirements of these dietary components must await further investigation.

\section{AMINO ACID DEFICIENCY}

Does the level at which maximal rates of protein turnover, particularly synthesis, are attained have any relevance to requirements for individual amino acids? Limited evidence 
from experiments in mammalian species suggests that the response of whole-body protein turnover to dietary amino acids is apparently the same as that to dietary protein. By changing dietary leucine from deficient to excess levels, Meredith et al. (1982) demonstrated that in humans whole-body protein synthesis was increased almost linearly to a breakpoint, probably representing the leucine intake required for maximum net protein accretion, from which the synthesis rate reached a constant value. These studies have been described in full and extended to include similar studies with valine and lysine (Meguid et al. 1986a, $b$; Meredith et al. 1986). A similar pattern of responses of whole-body protein synthesis to increasing protein intake was observed in rats (Laurent et al. 1984). In avian species, however, the answer to this question cannot be given because no comparable systematic studies are available. Therefore, the following description is restricted to qualitative changes in protein turnover when one or more essential amino acids are deficient in a diet. Another important question is the extent to which certain amino acids have a regulatory role in protein turnover in tissues such as liver and muscle in vivo, and thereby in the whole body. This concept is attractive to many scientists in the medical field. For example, Millward \& Rivers $(1988,1989)$ have introduced the concept of the anabolic drive to describe this regulatory influence of amino acids, arguing that such influences of nutrients should be included in the criteria by which nutrient requirements are assessed. However, this subject is beyond the scope of the present review, and the readers are referred to recent papers (Chua et al. 1979; Garlick \& Grant, 1988; Jepson et al. 1988 a; Millward, 1989).

It is legitimate to state, at present, that in avian species deficiency of any single essential amino acid would lead to a reduced rate of protein synthesis and possibly protein degradation in the whole body. Supplementing with these amino acids would then restore the lowered turnover rates. Hiramoto et al. (1990) found, for example, that in laying hens fed on either maize-gluten meal or isolated soya-bean protein as the only source of dietary protein to produce deficiency in lysine or methionine respectively, both protein synthesis and degradation rates in the whole body showed a remarkable enhancement when these amino acids were supplemented. The findings of reduced whole-body protein synthesis in young chicks when deprived of dietary sulphur-containing amino acids or histidine (Kino \& Okumura, 1987a) is also in line with the result in laying hens.

In mammalian species the effects of deficiency of a single essential amino acid are generally in good agreement. Conway et al. (1980) found in humans that supplementing a lysine-free diet with this amino acid substantially enhanced whole-body protein turnover rates. As already stated, leucine, valine or lysine deficiency brought about a reduction in whole-body protein synthesis in humans (Meredith et al. 1982, 1986; Meguid et al. $1986 a, b)$ and in rats (Laurent et al. 1984). In goats, Muramatsu et al. (1989) also found that supplementing a urea diet with methionine that is resistant to degradation in the rumen resulted in enhanced turnover rates in the whole body.

In growing pigs, in contrast, Fuller et al. (1987) failed to observe any significant changes in the whole-body protein synthesis by supplementing a diet believed to be deficient in lysine with this amino acid. As far as the response to amino acid deficiency is concerned, this is the only exception. Although the exact reasons for the anomaly in this particular species remain to be investigated, it is possible that the extent of lysine deficiency in their study was just not large enough to bring about any detectable changes in the whole-body protein turnover in growing pigs.

\section{AMINO ACID ADDITION TO A PROTEIN-FREE DIET}

Where young chickens were subjected to protein starvation, i.e. were made deficient in all essential amino acids, supplementing a protein-free diet with methionine in combination 
with arginine improved nitrogen balance (Muramatsu \& Okumura, 1979a, $b, 1980 a$ ). This enhanced whole-body protein synthesis, and to a lesser extent degradation (Muramatsu et al. 1986). The effect was also observed in the liver and the jejunal mucosa (Muramatsu et al. 1983), and to an even greater extent in skeletal muscle (Muramatsu et al. 1985b). Cystine and glutathione may bring about a similar response of enhanced whole-body protein synthesis in the presence of arginine in protein-starved chicks, as judged from the results of $\mathrm{N}$ balance studies (Muramatsu \& Okumura, 1980b: Muramatsu et al. 1984). This phenomenon might be thought surprising, since there is no amino acid given in the diet except for methionine and arginine. However, the $\mathrm{N}$-sparing effect of methionine alone or in combination with other amino acids has often been found in mammalian species, including dogs (Allison et al. 1947), pigs (Lubaszewska et al. 1973) and rats (Yoshida \& Moritoki, 1974; Yokogoshi \& Yoshida, 1979). Bearing in mind the fact that there is a large amount of amino acid flux due to whole-body protein degradation and re-synthesis even in the protein starvation state, improved $\mathrm{N}$ balance and enhanced whole-body protein turnover rates might be more understandable than it seems. In protein-starved animals, the amino acids released by proteolysis would appear to be deficient in methionine relative to the needs for synthesis. Biochemical evidence seems in favour of the possibility of relative deficiency of amino acid in protein-starved animals since methionine would probably be oxidized much faster than any other amino acids in rats and chickens (Aguilar et al. 1972; Neale \& Waterlow, 1983; Kino \& Okumura, 1987b). Bressani et al. (1965) also found larger values for urinary $\mathrm{S}: \mathrm{N}$ ratios in protein starvation than in normally fed dogs, suggesting a relatively greater loss of S-containing amino acids compared with others during protein depletion. In animals, methionine and cystine are also important constituents of feather, fur and hair proteins, being as much as $10 \%$ in the case of cystine (Mitchell, 1959). The component amino acids of these proteins are likely to be lost from skin surface, hence not returnable to the free amino acid pool once they are synthesized, and this would in turn accentuate the needs for S-containing amino acids in protein starvation.

Whatever the primary reason for bringing about the $\mathrm{N}$-sparing effect may be, all previously stated evidence supports the idea that the mitigation of deficiency of a certain essential amino acid, methionine in this particular case, would probably result in enhanced rates of whole-body protein turnover in chickens, even when they are subjected to protein starvation. The evidence so far obtained in mammalian species is circumstantial because no measurement on whole-body protein turnover rates has been attempted in conjunction with $\mathrm{N}$ balance studies. However, the enhanced whole-body protein turnover rates are very likely when a protein-free diet is supplemented with methionine, and the turnover responses between birds and mammals may well resemble each other in this respect.

\section{ACUTE EFFECTS}

Unlike chronic effects, the body of available evidence concerning acute effects on wholebody protein turnover are so limited in avian and mammalian species that any kind of formal comparisons are not possible at present. In the following section, therefore, much emphasis is placed on what is known in chickens together with pieces of relevant information in mammals.

\section{FASTING AND REFEEDING A DIET OR SPECIFIC NUTRIENTS}

Table 2 shows changes in whole-body protein synthesis in response to refeeding a single meal of a whole diet in chicks fasted for $48 \mathrm{~h}$ (Aoyagi et al. 1989). After the refeeding procedures, the whole-body protein synthesis rate, which was low as a result of fasting, 
Table 2. Effect of refeeding a single meal of semi-purified diet on fractional and absolute rates of protein synthesis in the whole body of fasted chicks (Taken from Aoyagi et al. 1989)

(Mean values for six chicks)

\begin{tabular}{|c|c|c|c|}
\hline & Treatment & $\begin{array}{c}\text { Fractional rate } \\
(\% / d)\end{array}$ & $\begin{array}{c}\text { Absolute rate } \\
\text { (g/kg body-wt per } d)\end{array}$ \\
\hline \multicolumn{2}{|l|}{ Fed } & $34 \cdot 0^{a}$ & $55 \cdot 4^{\mathrm{a}}$ \\
\hline Fasted & $(48 \mathrm{~h})$ & $23 \cdot 4^{\mathrm{d}}$ & $41 \cdot 7^{d}$ \\
\hline Refed: & $2 \mathrm{~h}$ & $28 \cdot 1^{\mathrm{C}}$ & $50 \cdot 0^{\text {bc }}$ \\
\hline & $6 \mathrm{~h}$ & $31 \cdot 1^{b}$ & $54 \cdot 3^{\mathrm{ab}}$ \\
\hline & $24 \mathrm{~h}$ & $27 \cdot 0^{r}$ & $48 \cdot 3^{c}$ \\
\hline Pooled & SEM $(25 d)$ & 1.0 & 1.7 \\
\hline
\end{tabular}

a, b, c Means with unlike superscript letters within the same column were significantly different $(P<0 \cdot 05)$.

significantly increased within $2 \mathrm{~h}$, although it did not completely recover to the full-fed state in terms of either the fractional or absolute rate. After $6 \mathrm{~h}$ of refeeding, the absolute rate almost returned to the prefasting level whilst the fractional rate did not. Because the amount contained in the meal was small, approximately half the daily food consumption, these values declined again at $24 \mathrm{~h}$ after the refeeding procedure.

These results clearly indicate that whole-body protein synthesis can respond to dietary alterations within as short a period as $2 \mathrm{~h}$ under conditions of total fasting followed by refeeding of a whole diet. The enhanced protein synthesis was primarily explained by an increase in protein synthesis per unit RNA, but not in terms of RNA:protein ratio. In fasted chickens, in contrast, Muramatsu et al. $(1987 a)$ found that a reduced fractional rate of protein synthesis in the whole body was accounted for by reductions in both protein synthesis per unit RNA and RNA:protein ratio compared with the fed state. It would appear, therefore, that the metabolic consequences of fasting on protein turnover involve mechanisms which cannot immediately be reversed during refeeding. The fact that the amount of total RNA remained low, and became even lower towards $24 \mathrm{~h}$ after refeeding, suggests that steps at translation rather than transcription were modulated during the early refeeding phase, possibly by increasing the rate of initiation of translation, which was inhibited due to fasting (Harmon et al. 1984), although this does not necessarily rule out the possibility of changes in transcriptional rates of mRNA.

Refeeding mixed diets in post-absorptive human subjects has resulted in different and conflicting responses of whole-body protein synthesis depending, probably, on the protein level employed and route of nutrient administration. Hoffer et al. (1985) found in humans a small but significant increase in whole-body protein synthesis when an adequate amount of protein was fed. When an amino acid mixture was administered parenterally to humans, Pacy et al. (1988) found a somewhat larger increase, $30 \%$, in whole-body protein synthesis compared with that of a fasted state. On the other hand, Melville et al. (1989) could not find any significant changes in whole-body protein synthesis in human subjects. Motil et al. $(1981 b)$ found in humans that at a very low level of protein intake there was a significant decrease in whole-body protein synthesis, whereas there was an increase at a marginally deficient level and no change at an excess level, the extent of alterations ranging from -15 to $15 \%$. However, the decreased response found by Motil et al. $(1981 a)$ at the very low protein intake could be considered as an extreme example when the balance of protein and energy in the meal is distorted considerably, and thereby can be regarded principally as an effect of carbohydrate or fat intake rather than protein intake per se, as discussed later. The 
reason for varied responses, from no change to an increase as large as $30 \%$, is not clear. Therefore, the consequence of protein consumption after fasting on whole-body protein synthesis in mammalian species could tentatively be defined as being unchanged or increased.

The response of whole-body protein degradation to refeeding of an adequate diet in the fasting state is not available for avian species. The evidence from human studies indicates that there is a considerable reduction, by $31-65 \%$, in whole-body protein degradation (Conway et al. 1980; Motil et al. 1981 ; ;offer et al. 1985; Melville et al. 1989). Melville et al. (1989), feeding adequate hourly meals, reached the conclusion that the acute regulation of whole-body protein kinetics, e.g. in response to meals, was primarily achieved by alterations in whole-body protein degradation. The inhibited degradation was also substantiated by parenteral administration of amino acids. When amino acids were infused intravenously, a reduction of about $20 \%$ in whole-body protein degradation was found (Pacy et al. 1988).

The reduced degradation after refeeding discussed previously is also observed in rat muscle in vitro (Li \& Wassner, 1984). There is good reason to assume that certain hormones such as insulin are involved in altered whole-body protein degradation. Refeeding a diet enhances the circulating level of insulin, and the increased insulin, in turn, reduces the muscle protein degradation in vitro ( $\mathrm{Li} \&$ Wassner, 1984). Thus, the hormone appears to play an important regulatory role in protein degradation as well as protein synthesis in the whole body. A number of studies also suggest the involvement of other hormones, but the subject is beyond the scope of the present review. The readers are referred to recent papers for further reading (Rabolli \& Martin, 1977; Millward et al. 1983, 1988; Garlick et al. 1985, 1988; Eisemann et al. 1986; Jepson et al. 1988b).

If a diet in which the balance of energy and protein is distorted is refed to fasted animals, the directions of the response of protein turnover rates are likely to be different. In chickens, our preliminary results indicated that the extent of changes in whole-body protein synthesis varied in response to meals consisting of carbohydrate, fat and protein ( $Y$. Aoyagi, T. Muramatsu \& J. Okumura, unpublished results). Likewise in mammals, Adibi et al. (1982) found unchanged total $\mathrm{N}$ flux with reduced amino acid oxidation by feeding exclusively carbohydrate to postabsorptive obese subjects, implying an increase in wholebody protein synthesis. Nair $e t$ al. (1988) also reported that in postabsorptive subjects the infusion of $\beta$-hydroxybutyrate resulted in elevated whole-body protein synthesis. These studies are relevant to the question of the relationship between diet-induced thermogenesis and protein turnover. However, further discussion will have to await the accumulation of a more concrete body of evidence.

\section{PROTEIN DEPLETION AND REPLETION}

Unlike the previously mentioned fasting-refeeding condition, where dietary energy is totally removed before the commencement of refeeding, the effect of nutrient depletion and repletion shows an entirely different response in the presence of an adequate energy intake throughout a treatment period.

In this category, the available information in avian species is exclusively limited to dietary protein consumption. During the course of protein depletion and repletion with an adequate energy supply, whole-body protein kinetics in laying hens were studied on a dayto-day basis. As might be expected, it was found that synthesis was decreased by feeding a protein-free diet. The rate of fall was rapid initially, but declined to almost a plateau basal level after $7 \mathrm{~d}$ of protein starvation (Muramatsu et al. 1987 c; see Fig. 5). A similar pattern of response was also observed for the rate of protein degradation, although it was less 


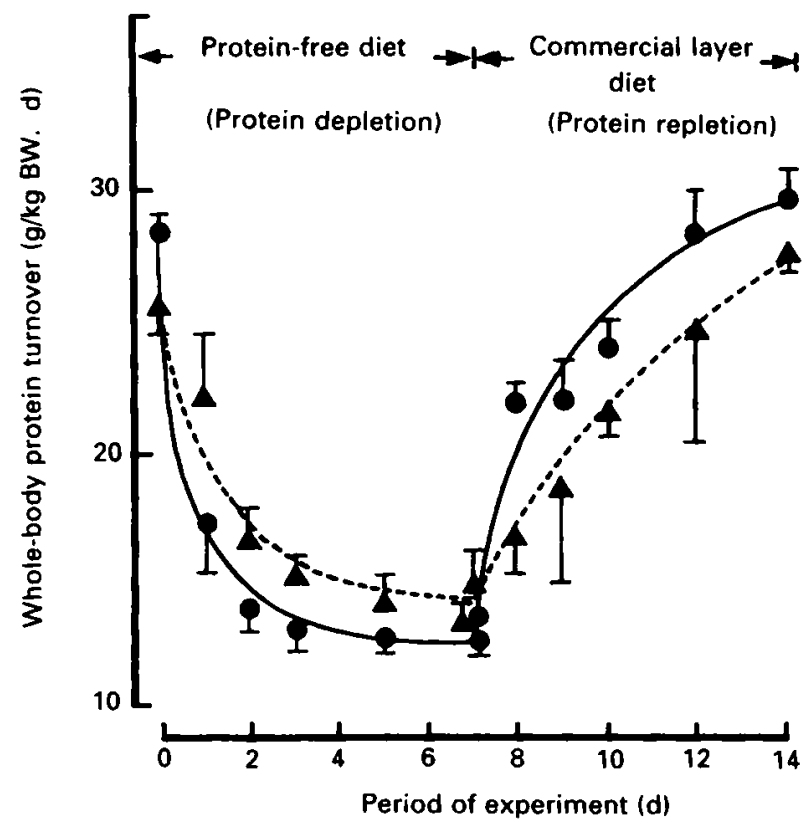

Fig. 5. Changes in whole-body protein turnover in laying hens fed on a protein-free (protein depletion) or commercial layer (Protein repletion) diet (-O), synthesis; $(\mathbf{A}-\mathbf{A})$, degradation; BW, bodyweight. Points are means with their standard errors represented by vertical bars. Mean values were significantly different from the corresponding initial values $(P<0.05)$. (Taken from Muramatsu $e t$ al. $1987 c)$.

pronounced. When a protein-containing diet was refed, whole-body protein synthesis and degradation increased promptly and sharply, although the changes in degradation were less marked. The protein turnover rates increased more rapidly for first 1-2 d, followed by a diminished incremental rate, and finally at $7 \mathrm{~d}$ of refeeding approached steady plateau rates that were similar to those in the pretreatment period.

An extraordinary aspect related to this finding in laying hens was the fact that almost half the reduction in the whole-body protein synthesis by protein starvation was accounted for by a reduction in that of the liver and oviduct (Muramatsu et al. 1987c). The high sensitivity of liver ind particularly the oviduct to the change in dietary protein supply is probably a specific property in this species, especially when they are at a laying stage. This is perhaps the consequence of long genetic selection for a high egg production rate and it is therefore not as surprising as it seems because both the liver and oviduct are the primary sites of egg yolk and albumen protein synthesis respectively. Obviously, the egg formation process involves the steroid-induced transcription of mRNA encoding egg proteins (Deeley et al. 1977; McKnight \& Palmiter, 1979; Sanders \& McKnight, 1985). However, the way in which alterations in nutrient supply interact with steroid-induced gene transcription is almost entirely unknown. Specific nutrients could affect the synthesis of DNA-binding regulatory proteins, their binding affinity, processing of premature mRNA or stabilization of mRNA.

In mammalian species, if there is a tissue comparable with the oviduct of laying hens, it would be the mammary gland of lactating animals. In rats, protein synthesis in mammary gland and liver was clearly influenced by dietary protein quality and feeding level, the changes being more remarkable in the mammary gland (Sampson \& Jansen, 1984, 1985; 
Table 3. Comparison of responses of whole-body protein turnover between avian and mammalian species in relation to nutritional status

\begin{tabular}{|c|c|c|c|}
\hline Species & & Avians & Mammals \\
\hline \multicolumn{4}{|c|}{ Chronic effect on synthesis } \\
\hline \multirow[t]{3}{*}{ Protein } & Deficient & Reduction & Reduction \\
\hline & Excess & No change & No change \\
\hline & Relevance to requirement & Possible & Possible \\
\hline \multirow[t]{3}{*}{ Energy } & Deficient & Reduction & No change (?) \\
\hline & Excess & No change & No change \\
\hline & Relevance to requirement & Possible & \\
\hline \multirow[t]{3}{*}{ Amino acid } & Deficient & Reduction & Reduction \\
\hline & Moderate excess & & No change \\
\hline & Relevance to requirement & ? & Possible \\
\hline \multirow{2}{*}{\multicolumn{4}{|c|}{$\begin{array}{l}\text { Acute effect on synthesis and degradation } \\
\text { Refeeding after total fasting }\end{array}$}} \\
\hline & & & \\
\hline & Synthesis & Elevation & Elevation or no change \\
\hline & Degradation & ? & Reduction \\
\hline \multicolumn{4}{|c|}{ Protein repletion after depletion } \\
\hline & Synthesis & Elevation & ? \\
\hline & Degradation & Elevation & ? \\
\hline
\end{tabular}

Sampson et al. 1986). After protein starvation for $1 \mathrm{~d}$ in lactating rats, Jansen \& Hunsaker (1986) reported that the sum of the reductions in protein synthesis in mammary gland and liver was about $8 \mathrm{~g} / \mathrm{kg}$ body-weight per $\mathrm{d}$. This amount corresponds to about $26 \%$ of the whole-body protein synthesis in rats fed on an adequate diet (McNurlan \& Garlick, 1980) and, therefore, probably accounts for a greater proportion of reduced whole-body protein synthesis during protein starvation.

\section{OUTLOOK AND CONCLUSIONS}

Whilst surveying the nutritional regulation of whole-body protein turnover in avian species in comparison with mammalian species it is clear that the current status of our understanding of the subject of protein turnover is far from complete. Table 3 summarizes what is known about whole-body protein turnover in a comparative form for avian and mammalian species. Although there is no a priori assumption that the control mechanisms are the same for the two species, the evidence presented hitherto has shown that the responses, and therefore underlying regulatory mechanisms, of whole-body protein turnover in avian species are not evidently different from those in mammalian species. This is true despite the fact that there is a clear contrast in the metabolism of some nutrients, such as the major nitrogenous end-product in urine, i.e. uric acid in birds and urea in mammals.

The literature on avian species shows that the acute consumption of a whole diet after total starvation or of a protein-containing diet after protein starvation leads to a rapid and prompt increase in whole-body protein synthesis. Chronic changes in protein and ME consumption from deficient to adequate levels also enhance whole-body protein synthesis, but there is no further increase at excess levels. This suggests that there may be a close quantitative relationship between whole-body protein synthesis and dietary protein and ME requirements. Unfortunately no information is available so far for other nutrients. In this regard, it is perhaps worth noting the statement of Young et al. (1987), who argued that more attention should be paid to protein kinetic studies in the whole body and to 
understanding the underlying mechanisms before hastening to draw a conclusion on the relationship between nutrient requirements and whole-body protein turnover.

The author is grateful to Dr P. J. Garlick, Rowett Research Institute, UK for his valuable suggestions on the preparation of the manuscript.

\section{REFERENCES}

Adibi, S. A., Stanko, R. T. \& Morse, E. L. (1982). Modulation of leucine oxidation and turnover by graded amounts of carbohydrate intake in obese subjects. Metabolism 31, $578-588$.

Aguilar, T. S., Harper, A. E. \& Benevenga, N. J. (1972). Efficiency of utilization of indispensable amino acids for growth by the rat. Journal of Nutrition 102, 1199-1208.

Allison, J. B., Anderson, J. A. \& Seeley, R. D. (1947). Some effects of methionine on the utilization of nitrogen in the adult dog. Journal of Nutrition 33, 361-370.

Aoyagi, Y., Muramatsu, T. \& Okumura, J. (1989). Contribution of whole-body protein synthesis to diet-induced thermogenesis in refed chicks. Nutrition Research (In the press.)

Bressani, R., Braham, J. E., Elias, L. G. \& Balconi, R. (1965). Urinary nitrogen and sulfur excretion in dogs under different dietary treatments. Journal of Nutrition $87,77-84$.

Chua, B., Siehl, D. L. \& Morgan, H. E. (1979). Effect of leucine and metabolites of branched chain amino acids on protein turnover in heart. Journal of Biological Chemistry 254, 8358-8362.

Conway, J. M., Bier, D. M., Motil, K. J., Burke, J. F. \& Young, V. R. (1980). Whole-body lysine flux in young adult men : effects of reduced total protein and of lysine intake. American Journal of Physiology 239, E192-E200.

Deeley, R. G., Gordon, J. I., Burns, A. T. H., Mullinix, K. P., Binastein, M. \& Goldberger, R. F. (1977). Primary activation of the vitellogenin gene in the rooster. Journal of Biological Chemistry 252, 8310-8319.

Eisemann, J. H., Hammond, A. C., Bauman, D. E., Reynolds, P. J., McCutcheon, S. N., Tyrrell, H. F. \& Haaland, G. L. (1986). Effect of bovine growth hormone administration on metabolism of growing Hereford heifers: protein and lipid metabolism and plasma concentrations of metabolites and hormones. Journal of Nutrition 116, 2504-2515.

Freeman, B. M. (1971). Metabolic energy and gaseous metabolism. In Physiology and Biochemistry of the Domestic Fowl, vol. I, pp. 279-293 [D. J. Bell and B. M. Freeman, editors]. London: Academic Press.

Fuller, M. F., Reeds, P. J., Cadenhead, A., Seve, B. \& Preston, T. (1987). Effects of the amount and quality of dietary protein on nitrogen metabolism and protein turnover of pigs. British Journal of Nutrition 58, $287-300$.

Garlick, P. J., Clugston, G. A. \& Waterlow, J. C., (1980a). Influence of low-energy diets on whole-body protein turnover in obese subjects. American Journal of Physiology 238, E235-E244.

Garlick, P. J. \& Grant, I. (1988). Amino acid infusion increases the sensitivity of muscle protein synthesis in vivo to insulin. Effect of branched-chain amino acids. Biochemical Journal 254, 579-584.

Garlick, P. J., McNurlan, M. A. \& McHardy, K. C. (1988). Factors controlling the deposition of primary nutrients. Proceedings of the Nutrition Society 47, 169-176.

Garlick, P. J., McNurlan, M. A. \& Preedy, V. R. (1980 b). A rapid and convenient technique for measuring the rate of protein synthesis in tissues by injection of $\left[{ }^{3} \mathrm{H}\right]$ phenylalanine. Biochemical Journal 192, 719-723.

Garlick, P. J., Preedy, V. R. \& Reeds, P. J. (1985). Regulation of protein turnover in vivo by insulin and amino acids. In Intracellular Protein Catabolism, pp. 555-564 [K. A. Edward, J. S. Bond and J. W. C. Bird, editors]. New York: Alan R. Liss, Inc.

Gersovitz, M., Bier, D., Matthews, D., Udall, J., Munro, H. N. \& Young, V. R. (1980). Dynamic aspects of whole body glycine metabolism: influence of protein intake in young adult and elderly males. Metabolism 29. $1087-1094$.

Harmon, C. S., Proud, C. G. \& Pain, V. M. (1984). Effects of starvation, diabetes and acute insulin treatment on the regulation of polypeptide-chain initiation in rat skeletal muscle. Biochemical Journal 223, 687-696.

Hiramoto, K., Muramatsu, T. \& Okumura, J. (1989). Underestimation of protein synthesis caused by using DLisomer of $\left[{ }^{15} \mathrm{~N}\right]$ methionine in laying hens. Nutrition Reports International 39, 635-642.

Hiramoto, K., Muramatsu, T. \& Okumura, J. (1990). Effect of methionine and lysine deficiencies on protein synthesis in the liver and oviduct and in the whole body of laying hens. Poultry Science 69, 84-89.

Hoffer, L. J., Bistrian, B. R., Young, V. R., Blackburn, G. L. \& Matthews, D. E. (1984). Metabolic effects of very low calorie weight reduction diets. Journal of Clinical Investigation 73, 750-758.

Hoffer, L. J., Yang, R. D., Matthews, D. E., Bistrian, B. R., Bier, D. M. \& Young, V. R. (1985). Effects of meal consumption on whole body leucine and alanine kinetics in young adult men. British Journal of Nutrition $\mathbf{5 3}$, 31-38.

Jansen, G. R. \& Hunsaker, H. (1986). Effect of dietary protein and energy on protein synthesis during lactation in rats. Journal Nutrition 116, 957.968.

Jepson, M. M., Bates, P. C., Broadbent, P., Pell, J. M. \& Millward, D. J. (1988a). Relationship between glutamine concentration and protein synthesis in rat skeletal muscle. American Journal of Physiology 255, E166-E172. 
Jepson, M. M., Bates, P. C. \& Millward, D. J. (1988b) The role of insulin and thyroid hormones in the regulation of muscle growth and protein turnover in response to dietary protein in the rat. British Journal of Nutrition $\mathbf{5 9}$, $397-415$

Kino, K. \& Okumura, J. (1987a). Whole-body protein turnover in chicks fed control, histidine, or methionine plus cystine-free diets. Poultry Science 66, 13921397.

Kino, K. \& Okumura, J. (1987 b). The different degradation rates of deficient amino acids in chicks fed a histidineor methionine plus cystine-free diet. Nutrition Reports International 36, 781-790.

Kita, K., Muramatsu, T. \& Okumura, J. $(1989 a)$. Influence of excess protein intake on whole-body protein synthesis in chicks. Nutrition Reports International 39, $1091-1097$.

Kita, K., Muramatsu, T., Tasaki, I. \& Okumura, J. (1989 b). Influence of dietary non-protein energy intake on whole-body protein turnover in chicks. British Journal of Nutrition 61, 235.244.

Laurent, B. C., Moldawer, L. L., Young, V. R., Bistrian, B. R. \& Blackburn, G. L. (1984). Whole-body leucine and muscle protein kinetics in rats fed varying protein intakes. American Journal of Physiology 246, E444-E451.

Laurent, G. J., Sparrow, M. P., Bates, P. C., Millward, D. J. \& Garlick, P. J. (1978). Turnover of muscle protein in the fowl (Gallus domesticus). Rates of protein synthesis in fast and slow skeletal, cardiac and smooth muscle of the adult fowl. Biochemical Journal 176, 393-405.

Li, J. B. \& Wassner, S. J. (1984). Effects of food deprivation and refeeding on total protein and actomyosin degradation. American Journal of Physiology 246, E32-E37.

Lobley, G. E., Connell, A. \& Buchan, V. (1987). Effect of food intake on protein and energy metabolism in finishing beef steers. British Journal of Nutrition 57, 457-465.

Lobley, G. E., Milne, V., Lovie, J. M., Reeds, P. J. \& Pennie, K. (1980). Whole body and tissue protein synthesis in cattle. British Journal of Nutrition 43, 491-502.

Lubaszewska, S., Pastuszewska, B. \& Kielanowski, J. (1973). The effect of methionine supplementation of a protein-free diet on the nitrogen excretion in rats and pigs. Zeitschrift für Tierphysiologie, Tierernährung und Futtermittelkunde 31, 120-128.

McKnight, G. S. \& Palmiter, R. D. (1979). Transcriptional regulation of the ovalubumin and conalbumin genes by steroid hormones in chick oviduct. Journal of Biological Chemistry 254, 9050-9058.

McNurlan, M. A. \& Garlick, P. J. (1980). Contribution of rat liver and gastrointestinal tract to whole-body protein synthesis in the rat. Biochemical Journal 186, 381-383.

McNurlan, M. A., Tomkins, A. M. \& Garlick, P. J. (1979). The effect of starvation on the rate of protein synthesis in rat liver and small intestine. Biochemical Journal 178, 373-379.

Meguid, M. M., Matthews, D. E., Bier, D. M., Meredith, C. N., Soeldner, J. S. \& Young, V. R. (1986a). Leucine kinetics at graded leucine intakes in young men. American Journal of Clinical Nutrition 43, 770780.

Meguid, M. M., Matthews, D. E., Bier, D. M., Meredith, C. N. \& Young, V. R. (1986b). Valine kinetics at graded valine intakes in young men. American Journal of Clinical Nutrition 43, 781-786.

Melville, S., McNurlan, M. A., McHardy, K. C., Broom, J., Milne, E., Calder, A. G. \& Garlick, P. J. (1989). The role of degradation in the acute control of protein balance in adult man: failure of feeding to stimulate protein synthesis as assessed by $\mathrm{L}-\left[1-{ }^{13} \mathrm{C}\right]$ leucine infusion. Metabolism 38, 248-255.

Mercer, L. P. (1982). The quantitative nutrient-response relationship. Journal of Nutrition 112, 560-566.

Meredith, C., Bier, D. M., Meguid, M. M., Matthews, D. E. Wen, Z. \& Young, V. R. (1982). Whole body amino acid turnover with ${ }^{13} \mathrm{C}$ tracers: a new approach for estimation of human amino acid requirements. In Clinical Nutrition '81, pp. 42-59 [R. I. C. Wesdorp and P. B. Soeters, editors]. London: Churchill Livingstone.

Meredith, C. N., Wen, Z.-M., Bier, D. M., Matthews, D. E. \& Young, V. R. (1986). Lysine kinetics at graded lysine intakes in young men. American Journal of Clinical Nutrition 43, 787-794.

Millward, D. J. (1989). The endocrine response to dietary protein: the anabolic drive on growth. In Milk Proteins, pp. 49-61 [C. A. Barth and E. Schlimme, editors]. Darmstadt: Steinkopf Verlag.

Millward, D. J., Bates, P. C., de Benoist, B., Brown, J. G., Cox, M., Halliday, D., Odedra, B. \& Rennie, M. J. (1983). Protein turnover : the nature of the phenomenon and its physiological regulation. In Protein Metabolism and Nutrition, 4th International Symposium, vol. 1, pp. 69-96. Paris: Institut National de la Recherche Agronomique.

Millward, D. J., Brown, J. G. \& van Bueren, J. (1988). The influence of plasma concentrations of triiodothyronine on the acute increases in insulin and muscle protein synthesis in the refed fasted rat. Journal of Endocrinology 118, 417-422.

Millward, D. J. \& Rivers, J. (1988). The nutritional role of indispensable amino acids and the metabolic basis for their requirements. European Journal of Clinical Nutrition 42, 367-393.

Millward, D. J. \& Rivers, J. P. W. (1989). The need for indispensable amino acids: the concept of the anabolic drive. Diabetes Metabolism Reviews 5, 191-212.

Mitchell, H. H. (1959). Some species and age differences in amino acid requirements. In Protein and Amino Acid Nutrition, pp. $11-43$ [A. A. Albanese, editor]. New York: Academic Press.

Motil, K. J., Bier, D. M., Matthews, D. E., Burke, J. F. \& Young, V. R. (1981a). Whole body leucine and lysine metabolism studied with $\left[1-{ }^{13} \mathrm{C}\right]$ leucine and $\left[\alpha^{15} \mathrm{~N}\right] l y s i n e:$ response in healthy young men given excess energy intake. Metabolism 30, 783-791.

Motil, K. J., Matthews, D. E., Bier, D. M., Burke, J. F., Munro, H. N. \& Young, V. R. (1981b). Whole-body 
leucine and lysine metabolism : response to dietary protein intake in young men. American Journal of Physiology 240, E712-E721.

Muramatsu, T., Aoyagi, Y., Okumura, J. \& Tasaki, I. (1987a). Contribution of whole-body protein synthesis to basal metabolism in layer and broiler chickens. British Journal of Nutrition 57, 269277.

Muramatsu, T., Coates, M. E., Hewitt, D., Salter, D. N. \& Garlick, P. J. (1983). The influence of the gut microflora on protein synthesis in liver and jejunal mucosa in chicks. British Journal of Nutrition 49, 453-462.

Muramatsu, T., Hatano, T., Ueda, Y., Furuse, M. \& Okumura, J. (1989). Effect of rumen-protected methionine on whole-body protein synthesis in goats. Asian-Australasian Journal of Animal Science 2, 247248.

Muramatsu, T., Hiramoto,. K., Tasaki, I. \& Okumura, J. (1987 b). Whole-body protein turnover in laying hens with special reference to protein depletion and repletion. Nutrition Reports International 35, $607-614$.

Muramatsu, T., Hiramoto, K., Tasaki, I. \& Okumura, J. (1987 c). Effect of protein starvation on protein turnover in liver, oviduct and whole body of laying hens. Comparative Biochemistry and Physiology 87B, 227-232.

Muramatsu. T., Kato, M., Tasaki, I. \& Okumura, J. (1986). Enhanced whole-body protein synthesis by methionine and arginine supplementation in protein-starved chicks. British Journal of Nutrition 55, 635-641.

Muramatsu, T., Kita, K., Tasaki, I. \& Okumura, J. (1987d). Influence of dietary protein intake on whole-body protein turnover in chicks. British Poultry Science 28, 471-482.

Muramatsu, T., Kita, K., Tasaki, I. \& Okumura, J. (1988a). Whole-body protein synthesis in chicks with special reference to dietary protein requirement. Japanese Journal of Zootechnical Science 59, 568-571.

Muramatsu, T., Nagai, N., Kino, K., Okumura, J. \& Tasaki, I. (1985a). Whole-body protein synthesis and amino acid metabolism in genetically obese and proteinuric mice. Nutrition Reports International 32, 1371 - 1377.

Muramatsu, T. \& Okumura, J. (1979a). Nitrogen sparing action of dietary methionine and arginine in chicks fed a protein-free diet. Nutrition Reports International 19, 335-342.

Muramatsu, T. \& Okumura, J. (1979 b). Effect of dietary methionine and arginine on uric acid excretion of cocks fed a protein-free diet. Journal of Nutrition 109, 1057-1062.

Muramatsu, T. \& Okumura, J. (1980a). Influence of dietary energy on the nitrogen sparing action of methionine and arginine in chicks fed a protein-free diet. Journal of Nutrition 110, 59-65.

Muramatsu, T. \& Okumura, J. $(1980 b)$. The nitrogen-sparing effect of methionine in chicks receiving a proteinfree diet supplemented with arginine: effect of various methionine substituents. British Poultry Science 21. 273280 .

Muramatsu, T. \& Okumura, J. (1985). Whole-body protein turnover in chicks at early stages of growth. Journal of Nutrition 115, 483-490.

Muramatsu, T., Salter, D. N. \& Coates, M. E. (1985b). Protein turnover of breast muscle in germ-free and conventional chicks. British Journal of Nutrition 54, 131-145.

Muramatsu, T., Ueda, Y., Hirata, T., Okumura, J. \& Tasaki, I. (1988b). A note on the effect of ageing on wholebody protein turn-over in goats. Animal Production 46, 479-481.

Muramatsu, T., Wakayama, E., Kato, M.. Tasaki, I. \& Okumura, J. (1984). The relationship between non-protein sulfhydryl compounds and the nitrogen-sparing action of amino acid supplements in protein-starved chicks. Japanese Journal of Zootechnical Science 55, 682693.

Nair, K. S., Welle, S. L., Halliday, D. \& Campbell, R. G. (1988). Effect of $\beta$-hydroxybutyrate on whole-body leucine kinetics and fractional mixed skeletal muscle protein synthesis in humans. Journal of Clinical Investigation 82, 198205.

National Research Council (1978). Nutrient Requirements of Laboratory Animals, 3rd revised ed., Washington, DC: National Academy of Sciences.

National Research Council (1984). Nutrient Requirements of Poultry, 8th revised ed., Washington, DC: National Academy Press.

Neale, R. J. \& Waterlow, J. C. (1983). Rate of endogenous methionine oxidation in rats at different levels of methionine intake. British Journal of Nutrition 50, 157162.

Pacy, P. J., Garrow, J. S., Ford, G. C., Merritt, H. \& Halliday, D. (1988). Influence of amino acid administration on whole-body leucine kinetics and resting metabolic rate in postabsorptive normal subjects. Clinical Science $75,225-231$.

Rabolli, D. \& Martin, R. J. (1977). Effects of diet composition on serum levels of insulin, thyroxine, triiodothyronine, growth hormone, and corticosterone in rats. Journal of Nutrition 107, $1068-1074$.

Reeds, P. J., Cadenhead, A., Fuller, M. F., Lobley, G. E. \& McDonald, J. D. (1980). Protein turnover in growing pigs. Effects of age and food intake. British Journal of Nutrition 43, 445-455.

Reeds, P. J. \& Fuller, M. F. (1983). Nutrient intake and protein turnover. Proceedings of Nutrition Society 42 , 463.471

Reeds, P. J., Fuller, M. F., Cadenhead, A., Lobley, G. E. \& McDonald, J. D. (1981). Effects of changes in the intakes of protein and non-protein energy on whole-body protein turnover in growing pigs. British Journal of Nutrition 45, 539- 546

Reeds, P. J. \& Lobley, G. E. (1980). Protein synthesis: are there real species differences? Proceedings of Nutrition Society 39, 4352.

Sampson, D. A., Hunsaker, H. A. \& Jansen, G. R. (1986). Dietary protein quality, protein quantity and food intake: effects on lactation and on protein synthesis and tissue composition in mammary tissue and liver in rats. Journal of Nutrition 116, 365-375. 
Sampson, D. A. \& Jansen, G. R. (1984). Protein synthesis during lactation: no circadian variation in mammary gland and liver of rats fed diets varying in protein quality and level of intake. Journal of Nutrition 114, 1470-1478.

Sampson, D. A. \& Jansen, G. R. (1985). The effect of dietary protein quality and feeding level on milk secretion and mammary protein synthesis in the rat. Journal of Pediatric Gastroenterology and Nutrition 4, $274-283$.

Sanders, M. M. \& McKnight, G. S. (1985). Chicken egg white genes: multihormonal regulation in a primary cell culture system. Endocrinology 116, 398-405.

Schimke, R. T. (1970). Regulation of protein degradation in mammalian tissues. In Mammalian Protein Metabolism, vol. 4, pp. 177228 [H. N. Munro, editor]. New York: Academic Press.

Schoenheimer, R. (1942). The Dynamic State of Body Constituents, pp. 3-78 (Revs H. T. Clarke, D. Rittenberg and S. Ratner, editors) Cambridge, MA : Harvard University Press.

Scott, M. L., Nesheim, M. C. \& Young, R. J. (1982). Nutrition of the Chicken 3rd ed., pp. 58-118. Ithaca, New York: M. L. Scott and Associates.

Smith, R. H. (1980). Comparative amino acid requirements. Proceedings of Nutrition Society 39, $71-78$.

Waterlow, J. C., Garlick, P. J. \& Millward, D. J. (1978). Protein Turnover in Mammalian Tissues and in the Whole Body, pp. 117 176, 371-401, 443 479. Amsterdam: North-Holland Publishing Co.

Webster, A. J. F. (1981). The energetic efficiency of metabolism. Proceedings of Nutrition Society 40, $121-128$.

Webster, A. J. F. (1983). Energetics of maintenance and growth. In Mammalian Thermogenesis, pp. 178-207 [L. Girardier and M. J. Stock, editors]. London: Chapman and Hall.

Winterer, J., Bistrian, B. R., Bilmazes, C., Blackburn, G. L. \& Young, V. R. (1980). Whole-body protein turnover, studied with ${ }^{15} \mathrm{~N}$-glycine and muscle protein breakdown in mildly obese subjects during a protein-sparing diet and a brief total fast. Metabolism 29, 575- 581 .

Yang, R. D., Matthews, D. E., Bier, D. M., Wen, Z. M. \& Young, V. R. (1986). Response of alanine metabolism in humans to manipulation of dietary protein and energy intakes. American Journal of Physiology 250 , E39-E46.

Yokogoshi, H. \& Yoshida, A. (1979). Effect of supplementation of methionine and threonine on hepatic polyribosome profile in rats meal-fed a protein-free diet. Journal of Nutrition 109, 148-154.

Yoshida, A. \& Moritoki, K. (1974). Nitrogen sparing action of methionine and threonine in rats receiving a protein free diet. Nutrition Reports International 9, 159168

Young, V. R., Cucalp, C., Rand, W. M., Matthews, D. E. \& Bier, D. M. (1987). Leucine kinetics during three weeks at submaintenance-to-maintenance intakes of leucine in man: adaptation and accommodation. Human Nutrition: Clinical Nutrition 41C, 118.

Zak, R., Martin, A. F. \& Blough, R. (1979). Assessment of protein turnover by use of radioisotopic tracers. Physiological Reviews, 59, 407447. 